\title{
Traditional Institution for Forest Conservation within a Changing Community: Insights from the Case of Upland South Sumatra
}

\author{
Edwin Martin ${ }^{1}$, Didik Suharjito ${ }^{2}$, Dudung Darusman ${ }^{2}$, Satyawan Sunito ${ }^{3}, \&$ Bondan Winarno $^{1}$ \\ ${ }^{1}$ Environment and Forestry R\&D, Institute of Palembang, Indonesia \\ ${ }^{2}$ Faculty of Forestry, Bogor Agricultural University, Indonesia \\ ${ }^{3}$ Faculty of Human Ecology, Bogor Agricultural University, Indonesia
}

DOI: http://dx.doi.org/10.15294/komunitas.v8i2.5439

Received : 15 March 2016; Accepted: 23 August 2016; Published: 30 September 2016

\begin{abstract}
Referring to the studies on the success of community forestry, the proponents suggest reducing the influence of the state to the people who maintain traditional institutions in forest management. However, knowledge about the interaction of formal and informal institutions in the context of changing smallholder farmers is still not fully understood. Through a phenomenological approach assessing the differences of forest conserving institutions'performance across villages in Semende, South Sumatra, it is analyzed the process of how traditional institutions can survive or collapse. The main finding shows that traditional institutions gained support and legitimacy from government's formal institutions to enforce the rules are able to survive until now. The key factor determining the success or failure of traditional institutions is the structure of community's authority; whether it is based on inherited knowledge or not. It is proposed a new hypothesis for the concept of local institutions that successfully manage natural resources.
\end{abstract}

Keywords: community forestry; phenomenology; protection forest; traditional institution; upland

\section{INTRODUCTION}

The proponents of community forestry refers to the results of studies describing the success of various communities in forest management (e.g.Lasco and Pulhin 2006; Pandit and Bevilacqua 2011). Meta-analysis of various research publications on case studies of forest management indicates the rate of deforestation in community-managed forest is lower than that of protection forest (Porter-Bolland et al. 2012). Research on 14 forested countries in Latin America, Afri$\mathrm{ca}$, and Asia concluded that countries that provide legal rights on forest tenure to indigenous and local communities are more capable to control deforestation than if the forests belong to the state (Stevens et al. 2014). People who have interacted with the natural environment for a long time, such as

\footnotetext{
Corresponding author:

Address: J1. Kol. H. Burlian Km 6,5 Palembang, Indonesia

Email : abinuha1976@yahoo.co.id
}

Kerinci People at upland Sumatra (Helida et al. 2015), Osing people at Banyuwangi East Java (Sumarmi 2015), Kanekes Sundanese traditional community (Indrawardana 2012), were reported to maintain their traditional forests successfully. According to these facts, countries are encouraged to create policies for legitimizing the rights of indigenous people on land(Hayes 2010).

The success of communities in managing forest is inseparable from the existence of local (Brown \& Sonwa 2015) or traditional institutions (Kajembe 2003). Forest conservation in Southern Madagascar is determined by taboo informal institutions, in the form of trust and sanction system, without any formal institution (Tengö et al. 2007). However, it is questionable whether the local institutions do not require the presence

(C) 2016 Semarang State University. All rights reserved p-ISSN 2086 - 5465 | e-ISSN 2460-7320 
of formal institutions created by the state, in the context of development in developing countries. A criticism on CBFM practice is that the concept simply separates the social and state entities ( $\mathrm{Li}$ 2002).

However, another study in Madagascar shows that community forest management does not guarantee the conservation of forests, especially for institutions allowing commerciality of resources (Rasolofoson et al. 2015). During this time, local institutional arrangement has proven to be able to conserve natural resources for centuries, but often fail in the event of rapid change (Dietz et al. 2003). Research on the resource management practices by communities in 6 countries concludes that there are several groups of people who managed to conserve the resource, but many of them failed (Kellert et al. 2000).

The disappointment regarding many failures made by traditional institutions in managing forests needs to be addressed with an in-depth analysis of the sociocultural dynamics in the management of common property resources (Campbell 2001). If the interaction between community, village government and forest is observed, then the claims of successful forest management devolved to the community is just an exaggeration(Brockington 2007). The implementation of community-based resource management in inappropriate situations actually triggers the destruction of resources (Kamoto et al. 2013). The research seeking to understand how the traditional institution of forest conservation can survive or collapse in a development context and changes, through the understanding of the actors themselves, is still limited.

Mowo et al. (2013) have conducted a research to understand the role of traditional local institutions in natural resource management in the highlands of East Africa, but have not been able to explain how the institutions can work in the past and what strategies to integrate the institutions with the formal system. Osei-Tutu et al. (2015) managed research on the interaction of formal and informal institutions in the context of forest management in Ghana. Their results showed that if the two institutions shared the same goal, they will be mutually reinforcing, although one of them is not working. The study did not explain how these different institutions can strengthen or weaken each other.

In Semende up land of Muara Enim, South Sumatra Indonesia, traditional institutions of natural forest conservation for maintaining the protection function of the forest has been running for decades, especially for forest that supply water for sawah (rice-field) irrigation. In recent years there were several cases of community behavioral change on guarding their forests, but some of them were still consistent. Considering the phenomenon, two questions are raised comprising: (1) why and how traditional institutions for forest conservation can survive or change? and(2) where is the role of the state in the process of maintenance or negligence of the traditional rules for community-based forest protection. This study aims to better understand the strengths and weaknesses of the traditional institutions of natural forest conservation when facing the challenges of change from outside and within themselves, based on their own experiences.

\section{METHOD}

\section{Case study and theoretical framework}

In this study, the institution is defined as a system of social rules that are embedded in a society and developed to become a framework of social interactions (Hodgson 2006). Institutions include formal and informal rules that control behavior. Formal rules are written rules established by the state, whereas the informal rules are the unwritten norms and culture but regulate the social and economic life (Casson et al. 2010). The community of Semende ethnical group has institutions for their rice farming system. For generations, groups of sawah owners have prohibited anyone for damaging the forest where the upstream water sources are located. The upstream water source is the area from the dam or the so-called babakan until the spring. Boundary of the upstream water region is all areas where the water flows to 


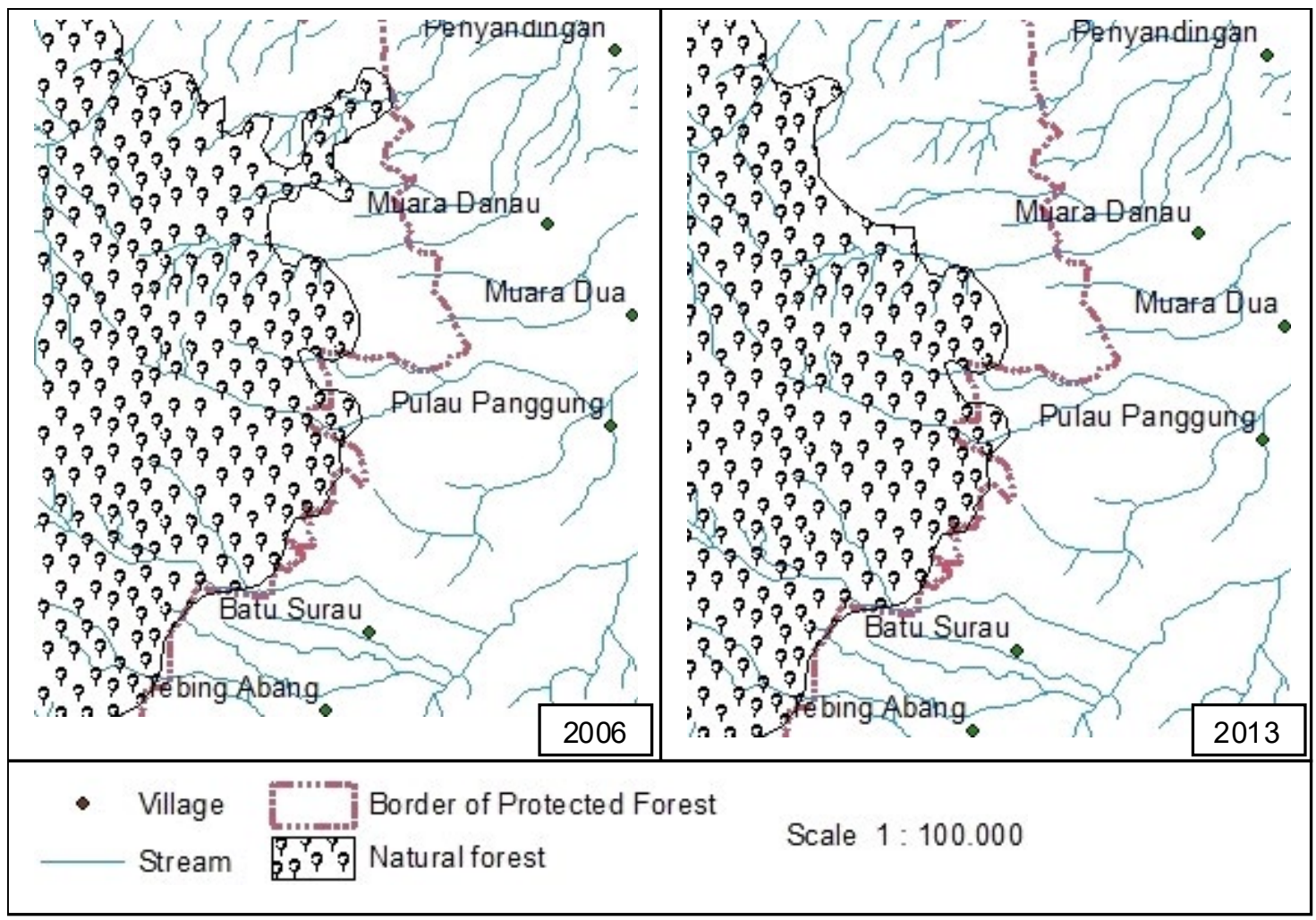

Figure 1. Forest cover changes in villages in the upstream water source of Semende, Muara Enim

the spring or drains toward the sawahs.

The performance of water conservation institution run by sawahowners is now beginning to vary between villages. The evidence can be seen through the appearance of the forest next to the villages which has been identified as the upstream water source. The case occurred in the area between Batu Surau and Muara Danau. The forest where upstream water is located, in Batu Surau Village, looks intact and beautiful, while in Muara Danau it has been partially transformed into coffee plantations (Figure 1).

Researches revealing the resilience of local institutions in natural resource management have been widely available. In general, the researchers used specific theoretical frameworks mentioning the determinants of institutional endurance to be empirically tested in the field, through a survey method or combining quantitative and qualitative techniques (e.g. Cox et al. 2010; Urech et al. 2013; Gatto and Bogataj 2015). The studies did not address the attribute required by lo- cal community or key factors to establish a durable institution, in relation to the challenges of change faced in their daily lives.

In this study, we use the preposition of Uphoff (1992) which describes the characteristics of successful local institutions in the context of development, as a theoretical framework. Uphoff (1992) states: "local institutions are more likely to be successful in natural resource management where the resource is "bounded", that is, known and predictable rather than shifting and variable, and where the users themselves are an identifiable group or community with its own authority structure" (p. 8). Resources, users, and the structure of authority became key concepts in the success of local institutions.

We chose a descriptive phenomenological approach, derived from Husserl philosophical idea, to trace and answer the research questions. Husserl believes that subjective information is important for scientists who want to understand human motivation, because human action 
is influenced by what they perceive reality (Flood 2010). The goal of phenomenological research is to understand the subjective nature of "life experience" from the perspective of the people who experienced it, by exploring the meanings and subjective explanations provided by the people (Cope 2003).

According to the basic philosophy of Husserl's phenomenology, the phenomenological research method includes the following steps (Giorgi 1997): (1) phenomenological reduction, (2) description, and (3) finding the essence. The fundamental assumption of Husserl's thought is revealing the essential components of an experience; therefore researchers must get rid of all the knowledge about the phenomena he researched (bracketing) to avoid personal bias and prejudice that blunts the findings (Finlay 2009). Along with that, Creswell (1998) describes in more detail the steps of phenomenological research adapted in this study including: the process approach and determination of participants, data collection, and reporting.

The approach and determination of participants are endless process. Participants consist of informants and subjects. Informants are local residents who are considered to have a lot of information about phenomenon being discussed and are always willing to assist investigators in the research process. Subjects are people who are considered to have knowledge, interests, and experiences of the upstream forest conservation institutions. The initial process to get the subject was visiting all households, in order to determine the general socio-economic characteristics and their interaction on the "protected forest" areas.

In every visit to the village, we lived with the informant's family for a few days and participate in their daily and agricultural activities. After the third visit and informants familiar with our desire to understand more about the phenomena of the surrounding forest, we discussed who deserves to be the subject of study and what questions should be addressed for each subject, in order to understand their experiences better. In the process of deepening the study, we decided to interview only 10 and 15 subjects respectively from Batu Surau and Muara Danau considering the saturation of information.

The main method of data collection in phenomenology is in-depth interviews (Wimpenny \& Gass 2000). The researcher began the in-depth interviews with the general question "why was the forest converted or not to coffee plantations", then always followed by a further question "why" and "how". We did not design the interview protocol with the available theory and terminology, in order to collect key aspects of participants' experiences, as suggested by Gioia et al (2012).

One of our in-depth interview strategies is always to clarify and reflect on the experience that has been delivered and further asked "why did it happen" or vice versa.This method is a form of imaginative variation as a fundamental requirement of phenomenological approach (Giorgi 2006), in order to bring intuition and eliminating non-essential features (Beech 1999). We equipped bracketing attitude by using field notes as a reflective "diary" to write down the observation results, assumptions, and confusions, as a way for reducing personal bias (Wojnar \& Swanson 2007).

Avoiding personal bias is an effort to improve the validity of research results (Noble \& Smith 2015). Another strategy to improve the validity and reliability of data is by extending the period of study; asking about the same issue in different agricultural seasons, discussing the findings with the informant, asking again to the subject if it finds doubts, and presenting/publishing preliminary findings to colleagues. The researcher conducted several visits to the village to participate in the farming cycle period, from December 2013 to December 2014.

Transcripts of the interviews were analyzed through three stages, namely horizontalization, cluster of meaning, and a description of the essence (Creswell 1998). Field notes help describing a broader meaning and essence of the subject's experiences. Description of the research results was discussed with the informants in detail before it goes to final description. We used 
special code to replace participant's original name in the report result.

\section{RESULT AND DISCUSSION}

\section{Socio-cultural characteristics of the participants}

Tradition that is practiced, proud and taught from generation to generation by the Semende isbemeraje anak belai. Structures that are always present in this culture are meraje and anak belai. Meraje is the brother of the mother and anak belai is all descendants of meraje's sisters. The central element of anak belai is called tunggu tubang. Tunggu tubang is the eldest daughter in a family. Tunggu tubang is assigned to guard the house and other treasures, such as sawahs, gardens, and ponds in order to take care of her entire family. The eldest daughter gets the status of tunggu tubang if already married. The most basic obligation of the spouse of the tunggu tubang is taking care of the elderly.

In carrying out her tasks as custodian of the ancestral treasures, tunggu tubang is guided, nurtured, and supervised by meraje. Treasures such as houses and sawahs may only be occupied, cultivated, and enjoyed for the yields, but forbidden to be sold or mortgaged. Meraje has the right to advice, give warning and sanctions if the tunggu tubang violates the customary rules. Beside the meraje, other respected clan is lautan. All the brothers of the wife is called lautan by the husband.

Semende people call children other than the tunggu tubang as anak tengah. It is only tunggu tubang who will stay and manage the houses, sawahs, and gardens of ancestor's inheritance. Anak tengah should be able to live independently. Anak tengah who managed to build or acquire sawahs and houses will inherit their properties to the eldest daughter, forming a new tunggu tubang.

Semende people occupy 32 villages in Muara Enim, South Sumatra. They are located in the ridge line of Bukit Barisan. Even though their villages are located in the plateau area, the transportation and communi- cation in the region that can be reached within 8 hours from Palembang is quite good. The status of a village as a new administrative territory determines the socio-economic characteristics of its villagers. Batu Surau is a separated from Muara Tenang Village, while Muara Danau is one of the old villages in Semende. Villagers in Batu Surau are more diverse than Muara Danau. Most of household heads in Batu Surau are not native. An opposite situation occurred in Muara Danau.

Although the village of Batu Surau and Muara Danau featured a different performance of upstream forest conservation institutions, we obtained 4 similar themes to answer the research questions. The four groups are: 1) value preferences; 2) space allocation; 3) past experiences; 4) local authority role.

\section{Batu Surau Village: "It's our forest, we look after it"}

\section{Value preferences}

For the villagers of Batu Surau, ghimbeulu ayekis all forests located in the upstream of sawahs, starting from the fountain called entup-entup, the water flows through a small river called Enim Tak Berikan, until it is deflected by a dam known as babakan. It then heads to the sawahs and passes the irrigation, called siring. They defined forests as the area with natural vegetation that is until now has never converted into sawahs or coffee plantations. BS-1, age 60 years old, head of the village former,mentioned:

"Ulu ayek is the upstream area of sawahs that cannot be converted into sawahs, determined by ancestors who made the siring. In the past, when the ancestors built the irrigation, they made a decision that the area of siring at the top should not be converted, the boundaries are not built with natural signs, but all villagers knew the boundaries".

The forest of ulu ayekin Batu Surau is maintained up to present. They conserved the forest to maintain the continuity of water and of the sustainability of the irrigation 
system. BS-2, currently is a head of village, explained why the forest is undisturbed:

\begin{abstract}
"It is a mandate from our ancestors that the forest surrounding the fountain should not be disturbed, and one next to the siring as well. We seriously maintain the siring from destruction because siring is the one that actually want to be maintained. If the trees are cut down, there is nothing to hold the soil, then the landslide, and the siring is broken".
\end{abstract}

The ancestors made siring to distribute water for sawahs and household's needs. According to BS-3, the informant, the forest of ulu ayek produces water for people's livelihoods so that they always maintain it.

\section{Space allocation}

The research subjects and informants explain more on why the forest of ulu ayek remains conserved. Batu Surau is created by the ancestors as the sawah expansion area for the village of Muara Tenang. According to the public figures' story, their ancestors deliberately opened up the sawahs here because it is close to a water source, although it has a mountainous topography. The water source is a small river that also utilized by Pulau Panggung villagers located in the downstream. Hence, the forest of ulu ayek in Batu Surau is a water source for a vast sawahs. BS-1explained more about the siring which derived from the forest of ulu ayek:

"From the hill of Tenam Bandung, there is 6 sirings, namely: Siring Sinar Benteng for irrigating sawahs in Batu Surau and Tebing Abang; Siring Baru and Pagar Embun as a water source for Batu Surau;Siring Padang Rigis, Bukit, and Talang Dengung for irrigating sawahs in Pulau Panggung, so the user are many.. The forest rangers are also many".

In Batu Surau, there are 150 hectares of sawahs that are managed by local communities and the owners of Tebing Abang and Muara Tenang Villages. In general, a family of tunggu tubang possesses 1 up to 1.5 hectare of sawahs. The owner of sawahs is also called as tuan siring. They are usually concerned with the siring's condition and the sustainability of water flow. Tuan siring has the right to prohibit or manage the situation in the forest of ulu ayek. Tuan siring only pay attention to the forest area surrounding siring and the fountains. BS-4, an anak tengah, age 34 years old, did not have any sawah or garden, forced to make a garden far from his village, he stated, "I do not dare to make a garden in the forest because tuan siring would get angry".

\section{Past experiences}

The hesitancy of some farmers to convert the forest of ulu ayek into coffee plantations has two basic references. Firstly, past stories those are not experienced directly by the subjects and the informants but still told by everyone. Secondly, justification for the actions of the ancestors by public figures especially the heads of village and their staffs. These references became the dominant discourse that always retold if members of community raise the issue of the forest of ulu ayek.

That beautiful forest was previously opened by the community. It was the period of Japanese occupation and the community experienced food crises. Farmers did not dare to grow rice in the sawahs. They were forced to grow rice in the forest. When the miserable period ended, the sawahs in the forest were abandoned and the area is recovered into forest again until now. BS-1 told, "according to our grandmother's story, the forest once was borrowed for swidden farming, but the rice tasted bitter, then returned again into the forest". The action of the ancestors to restore the forest after being converted into swidden farming is considered that the area should remain a forest.

Conservative attitudes persistently held by the public figures toward the tradition of ulu ayek forest. BS- 5 , age 61 years old, a village adviser, responded to the researcher's question "What if tomorrow there is a villager who open the forest to make coffee plantation", he answered:

"It is inherited by our ancestors, if you only 
take the wood for your own needs is permissible, but it is forbidden for gardening ... if someone opens the forest, he/she will be visited by people from the three villages ... what reasons make you open this forest ... we let it as a forest for hundreds years ... why do you dare to open it...."

\section{Local authority role}

When the research was begun in 2013, the villagers of Batu Surau witnessed deforestation in the forest of ulu ayek that was masterminded by community leaders at neighbouring village. Although the perpetrators are prominent figures from other village, but their actions to cut the timber in the forest of ulu ayek were sanctioned by the sawah owners. The perpetrators were reported to police with allegations of illegal logging in protection forests.

Until now, sawah owners are still cohesive to fight anyone who disturb the forest of ulu ayek. BS-1 told a case in the past:

"In the past, when we experienced famine, many people took bark of medang liot tree to be sold, some people from Gunung Agung Village penetrated the bark from our forest of ulu ayek... almost all villagers of this village came to the location of barking...they ran...although they made a hut already ... our people shouting ... this is our forest, we protect it ... we do not dare to take the bark out of here ...."

Attempts to open the forest area in the same hills but in far from water sources also occurred. These actions were immediately stopped by the sawah owners from Pulau Panggung Village. The perpetrators do not dare to continue their efforts because they do not have a good reason for their actions. Social coercion to enforce a ban on ulu ayek forest destruction was supported by village goverment.

The village government is aware of the desire of certain individuals to convert the forest around the village into a coffee plantation. Hence, the village government's wish to continue the tradition of forest conservation at ulu ayek should comply with the policy of higher government level. S-1, the informant, Forestry Officer, recounted his experience in the Batu Surau:

"At the time of reconstruction of protection forest boundaries in 2010, forest area boundaries of Batu Surau was actually at the top ... but a companion of Batu Surau asked the boundaries should be placed further down to protect forests in the sawah upstream... the companion said if the boundaries is located in the higher place, then the forest outside the region could be destructed by the people".

The village government regulates the relationship of villagers, but has no authority to apply sanctions. Until now, the village government becomes a major supporter for the conservation of the forest of ulu ayek. BS-3, the village secretary, described the two roles:

"There are two laws in the forest of ulu ayek, namely customary law and government law. Using customary law, perpetrators of the forest destruction would be reproved, called, and warned. However, if they continue their actions will be filed with the higher government, government law will be applied, that is what happened in the previous logging case".

\section{Muara Danau Village: "If one's dam- aged, all will be damaged"}

\section{Value preference}

The question of why the forest of ulu ayek was converted to coffee plantations was quickly responded by the informant and the subject with the answer "Coffee garden is a livelihood for anak tengah". Nevertheless, smallholder coffee farmers in the area of former ulu ayek's forest located adjacent to the settlement factually included all groups, either tunggu tubang or anak tengah. Coffee plantations are considered as quick yield farming. MD-1, the informant, aged 45 years old, mentioned:

"The welfare of rural communities here increased since the forest was turned into coffee plantations ... farmers hardly get progress if only plant paddy in the 
sawahs... if there is a coffee plantation we could go to Hajj, buy vehicles, repair houses, send kids to schools... especially now when the population is more and more ... our needs are increasing".

Extreme statements often arose if a stranger asks about the reasons of the conversion of ulu ayek's forest. MD-2, age more than 80 years old, stated, "In the past, sawah owners forbid forest clearing ... now it could not be prevented anymore ... they said, if we do not garden here we will die ... so rather than die, it is better to convert the forest area into gardens". Current circumstances have forced villagers to defeat their fear of the water problem for sawahs. MD-3, a sawah owner who also establishes coffee plantations in ulu ayek said: "It has been damaged already Sir ... if one's broken, all are broken ... if I did not join in the establishment of gardens I may get the impact, but for the benefits [of coffee plantation business] I will bite my own fingers".

\section{Space allocation}

Further reason for the clearing of some parts of ulu ayek's forest area in Muara Danau is associated with the rationality of the position of ulu ayek's forest. The boundaries of ulu ayek's forest are dynamic and subjective, though it was only one at first. MD-4, a former village head between 1986 and 1993 explained:

\footnotetext{
"Ulu ayek is the area from babakan up to the upstream. At the time I was head of the village, no one was opening the area at all, because it served as the ulu ayek of this village and Penyandingan Village ... at my era, the ban to open the forest of ulu ayek was resulted from a village meeting... the agreement letter lost after I retired from the village head".
}

The ulu ayek that is strictly forbidden to be disturbed is around the fountain of Ayek Betung, the largest river in the village. There are 46 sawah owners using irrigation of Ayek Betung. The irrigation is also used as a source of clean water for the village. In addition to Ayek Betung, there are other water streams that are also used for sawahs in $\mathrm{Mu}-$ ara Danau, namely Betung Ghenik and Batu Abang, each stream irrigates 11 and 3 sawahs respectively. Another river upstream located in Muara Danau is Perapau River, the sawah upstream for Penyandingan. However, the area surrounding the fountain of the three rivers now has turned into a coffee plantation. MD-5 stated:

"Actually, the whole area is ulu ayek, but the area that really should not be opened is luang dalam, it is the prohibited land, the really ulu ayek in this village, if it is inside the protection forests, it then is ok".

The redefinition of ulu ayek's forest area is then followed by the change of forest boundaries by the government, but it was not accompanied by dissemination to the public. Forest areas, for them, are the undisturbed forest and limited by BW label boundary markers made by the Dutch colonial administration. In 1980, the government conducted boundaries of protection forest by installing boundary markers in the lower area of the BW markers. In 1995, the boundaries were shifted further down. According to some former village heads, the forest authority never disseminated the meaning of boundaries in the three times boundary marking changes. They only call the boundaries as protection forest boundaries. This leads to differences in the interpretation of forest areas as justification for the action.

\section{Past experiences}

As a general story on Semende, in ancient times, the forest area had been used as an area of community's farming but then let it turns back into a forest. MD-6, age approximately 80 years old, recalled, "In 1963, sawah production was not sufficient for many family members ... the krie (village head) lent us a forest area for farming, growing sweet potatoes, then after two years we moved again. The areas where the sweet potatoes grew were then allowed to turn back into the forest. The areas where the durian grew were also allowed to turn back into the forest, but the durian stands remain exist. The durian 
stands were forming secondary forest called ghepangan. Re-opening the ghepangan became the first reason to open the ulu ayek's forest, as it was told by MD-1:

"As far as I know, the first person who opened the forest is ... he/she owned ghepangan in that area... During the durian season, they do weeding, but it is extended followed by the planting of coffee".

The first conversion of ulu ayek's forest into gardens was conducted in 1998. The sawah owners protested the action, but the actors who are also sawah owners have another excuse and were defended by the village head. MD-4 reviewed the story in that year:

"The late... at that time, he was old, no longer able to grow coffee in a distant place...he argued simply repeating his grandfather's job, then he made coffee plantations there ... Other sawah owners protested, but he said that the he was the only man that damaged the environment".

The first person who opened the forest of ulu ayek is a village elder and the lautan of village head at that time. MD-7, one of the opponents of clearing the ulu ayek's forest submitted the complaints, "He was my father-in-law, I forbade him, but he was smarter than me ... he said the status of the land was sawah". MD-4said, "We couldn't argue with the old people, they said that, although the forest was still intact, the water definitely shrink during the dry season and was abundant during the rainy season".

At the same time, there was a farmer who got a misery, so the village head allowed him to establish a garden in the upstream of Betung Ghenik. The permission triggered other farmers to open the forest of ulu ayek, particularly in the area of Talang Dengung, from the hill to the upstream of sawahs in another villages. MD-4 conveyed his memory about the number of the first people who opened the forest of ulu ayek, "at the beginning of the mass clearing of the forest, there were 24 people cleared the area of Talang Dengung, 2 people in Talang Baghu, and 2 people in Ayek Betung ... it turned out to be safe".

\section{Local Authority role}

The story of mass clearing of ulu ayek's forest occurred in 2005 and 2007 , explaining further about how traditional institutions of ulu ayek's forest can collapse. Inherited rules to conserve ulu ayek's forest could not be enforced by the sawah owners because they or their family violated the rules. Village government was not able to act decisively because they and their families were also in the violating process. In 2010, more than 200 ha of protection forests (mostly ulu ayek's forest) turned into coffee plantations.

After the first farmers who cleared the forest harvested the coffee and did not get any sanctions, other sawah owners finally joined in the forest clearance to grow coffee. The actions carried out individually, without any coordination. According to MD-4, the reason of his actions to clear the forest was similar to other villagers, namely "ngape jeme, ngape aku" means if other people can do, I can do it too.

At the time of mass clearing, the village head reported to the forestry authority and encouraged the sawah owners from the Penyandingan to stop deforestation. However, the efforts to stop it failed. The current village head explained that the failure occurred because people do not obey the leaders who had inconsistency between their words and deeds. MD-8 said,"The former village head could not stop the forest clearing because he and his family also clear the areas in Talang Dengung".

The sawah owners who use the water from Betung Ghenik tried to fight the forest clearing in the upstream, but they faced their own families. MD-9 told the story of their resistance:

\footnotetext{
"...we fear of the water shortage for our sawahs, we already gave a warn to those who cut down the forest, but they continued to make gardens there, may be they were smarter ... they said, it was not your forest, we could not force them to stop because we were all had family relationship... because other people made gardens finally we joined to clear the forest too"
} 
Regrets over the clearing of ulu ayek's forest was still shown by the sawah owners, because the actors were themselves. MD-4 revealed, "...MD-1 for example, he was the contact person of forest authorities, but his mother cleared the forest... I myself wanted to stop but did not know how... my lautan's son only had that job ... it was impossible if MD-1 must stop his mother, it was impossible too if I had to see my lautan's son suffered ... so the forest issues could not be resolved by the people themselves". Fighting back with making complaints to government's officers and agencies was also useless. MD-7, one of the farmers who fought back conveyed his complaints:

"In 2007, I was with the support of some sawah owners reported the clearance of ulu ayek's forest to the Forest Office ... I commuted to Muara Enim up to 5 times ... they paused for a while and then continued again ....".

The succession of village head and the new order regime enabled the redefinition of ulu ayek's forest in Muara Danau communities. In the era before 1998, the forest of ulu ayek located along streams from babakan to the fountain was undisturbed at all, including the surrounding protection forests. MD-4 recounted, "When I was the head of village, there was a deforestation activity done by police officers, but we could stop them". The figure of the head of village who protected the ulu ayek's institutions must be consistent, assertive, and willing to exercise direct supervision. Related to this, MD-7 said ... "At that time MD-4 directly supervised the fields and resolved violations immediately, but the next head of village did not do it".

The first converted location of ulu ayek's forest is Talang Dengung. This area is an ulu ayek for another village, but it was part of Muara Danau. In 1998, the head of village accompanied by several village staffs looked for some specific areas that are no longer included in the forest area as a result of boundary changes. They converted the area into coffee plantations. One of the village staffs who assisted the forest clearing then became the next head of village. This action triggered and justified the mass action of ulu ayek's forest clearing in the location of Ayek Betung and Talang Baghu, the upstream of their own sawahs.

\section{DISCUSSION}

This phenomenological approach-based research reveals actors at the local community level in an attempt to conserve or convert forests. The social actors deliver their experiences and understanding on the phenomena where forest that is traditionally conserved collectively but receives threats from outside and inside. Efforts to strengthen the performance of community-based resource management requires an analysis of how the social actors act collectively in facing changes (Armitage 2005). We obtain the essence of strengths and weaknesses of the traditional institution of natural forest conservation from experiences of the actors when they face the challenges of change.

The essence of strengths and weaknesses of the traditional institution of natural forest conservation in this study are preference values, space allocation, past experiences, and the role of local authority that are obtained by an "onion peeling" process. However, the essence is not in the deepest part as illustrated by Husserl, but each "layer of the onion" displays the essence. The whole essence forms an integrated system to answer the research questions. According to the concept of Uphoff (1992) on sustainable local institutions, "the preferences value" is the desired and regulated resources. The resources are attached to the definition of the users in the form of "space allocation". Rules as an institution will be sustainable if the users enforce sanctions for violators with support of "local authority role". In addition, the strength of the social structure in order to maintain the institution requires a knowledge reference in the form of "past experiences".

Changes through the dynamic of knowledge and development force institutions to endure or change. The institution of natural forest conservation emerges when peop- 
le want a guarantee of water resource supply for their sawahs. In this case, the managed forest is a prerequisite and not directly related to the fulfillment of common needs, namely food. On the other hand, the current needs for food can be fulfilled without having sawah farming. In such situations, the institution survives if the users put knowledge of the elderly people that shapes the institution as "a truth". Rules as an institution are considered to be permanent but flexible, so that under a certain condition that requires changes in the form of needed resources the change is only temporary and return to the original rules if the conditions had been normal.Wakjira et al. (2013) analyze the historical series in local institutions of Harenna forest management in Ethiopia. They conclude that adaptive institution is essential to sustainable development. Our findings provide nuance to the concept of the adaptive institutions. Community managed natural forests are sustainable if the institutions are permanent but adaptive. This is the real power of the traditional institutions of forest management.

Our research corroborates a research by $\mathrm{Li}$ (2002) which discusses the economic and cultural changes in upland communities in the context of the application of CBFM. We focus on the internal socio-political processes in community that may strengthen or weaken the institution of natural forest conservation. Results of this study patch lack of knowledge about how the system of community to cope and defend against threats from outside and inside, as also suggested by McCay and Jentoft (1998) and Tang and Tang (2010).

The success of a village in conserving the water upstream forests, such as Batu Surau Village, has a history where the heads of village were always able to harmonize the institution of sawahs-upstream forest with formal institutions of forest areas. Thus, the sustainability of water upstream forest is secured through informal institutions that is formed by the sawah owners, protected by state formal rules in the form of forest areas, and facilitated by reliable local governments. This is a model of CBFM that gets local legitimacy and succeed to achieve socio-economic and environmental objectives (see Brown \& Lassoie 2010). The village administration as facilitators to bridge the informal and formal institutions is an authority structure allowing the traditional institutions of forest conservation of upstream area possible to be sustained.

In the case of weakening traditional institutions for protection of forest conservation in Muara Danau, the government plays a role in creating the certainty or uncertainty of local level knowledge. The demarcation of protection forest areas without dissemination processes and ignoring the position of sawahs as cultural objects creates knowledge uncertainty. Knowledge contestation between actors in the village occurs when the elders' willingness to expand farmland gains an opportunity to be stronger. In turn, the area that is informally and formally designated as forests is converted into coffee plantations. The presence of government by opening the communication channel without blaming the actions of community has stopped the mass forest conversion. However, local community needs partnership with the government to continuously improve their livelihoods and conserve their forest resources (Chen et al. 2012).

The presence, communication, rewards, and knowledge provision are the roles of government officials to reinforce the legitimacy of local institutions of water upstream forest that is almost disappear. Research by Dixon and Wood (2007) concludes that local institutions requires external institutions to maintain their legitimacy, but they have not explained the roles of the external institutions. If government officials are knowledgeable and are believed can play a role as a local NGO leadership, it will encourage revitalizing an almost collapsed institutions. This is in-line with the results of the analysis of Werthmann (2015).

Results of this study complements previous knowledge about the interaction of formal and informal institutions in the context of forest management (see Mowo et al. 2013; Rahman et al. 2014; Osei-Tutu et al. 2015). Informal institution of natural forest 
conservation worked effectively in the past because users are socially recognized as an authority to enforce the rules and in situations where land is still widely available. In current situations, informal institutions can survive if the entity of leadership poses the elderly people knowledge as a "truth" and try to adjust to the established institutions formed by the state. The structure of authority that ensures the consistency and affirmation of informal institutions within the state formality framework plays an important role for the survival of traditional institutions on natural forest conservation, in the midst of preference changes of the resources and users.

The community of Semende is an open community practicing strong customs. This study has shown that in the everyday life people need the presence of the state through its formal institutions to support upstream forest conservation. Strengthening community-based forestry practices does not mean reducing the roles of government, but an understanding of how to play the role in diverse characteristics of local communities. Removing the government's role in community forest management is a failure, when viewed from the perspective of the importance of forest conservation.

\section{CONCLUSION AND SUGGESTION}

Understanding the strengths and weaknesses of the traditional institution of natural forest conservation when facing the challenges of change from outside and inside is an important pillar for forest conservation and development. Semende communities in the uplands of Sumatera, like most traditional farming communities in developing countries, are experiencing changes due to development. Community groups who manage to conserve their natural forests until now, placing the rules of ancestors as supremacy, so the pressure of changes must adjust that belief. We propose a new hypothesis for a successful local institution in managing natural resources within a changed traditional community. Traditional institutions can survive if the authority structure-backed users put resources as the first priority in their lives and make knowledge that forms the institution as truths.

The devolution of forest management to the community does not mean eliminating the roles of government in ensuring forest sustainability. Government officials must be able to understand a variety of different characteristics between units of local communities to recognize the role that is required by the community. Local knowledge that forms the traditional institutions is an asset to strengthen the conservation of natural forests. State authorities must ensure that any form of community forestry policy is the manifestation of informal institutions that are strengthened by the formal institutions of the state, not as a separate or different entity.

\section{ACKNOWLEDGEMENT}

We would like to thank all participants in this study. This study was funded by the DIPA BPK Palembang of the year 2013-2014.

\section{REFERENCES}

Armitage, D., 2005. Adaptive capacity and community-based natural resource management. Environmental Management, 35(6), pp.703-715.

Beech, I., 1999. Bracketing in phenomenological research. Nurse Researcher, 6, pp.35-51.

Brockington, D., 2007. Forests, community conservation, and local government performance: The village forest reserves of Tanzania. Society $\mathcal{E}$ Natural Resources, 20, pp.835-848.

Brown, H.C.P. \& Lassoie, J.P., 2010. Institutional choice and local legitimacy in community-based forest management: lessons from Cameroon. Environmental Conservation, 37(3), pp.261-269.

Brown, H.C.P. \& Sonwa, D.J., 2015. Rural local institutions and climate change adaptation in forest communities in Cameroon. Ecology and Society, $20(2)$, p.6.

Campbell, B., 2001. Challenges to proponents of common property resource system : Despairing voices from the social forest of zimbambwe. World development, 29(4), pp.589-6oo.

Casson, M.C., Della Giusta, M. \& Kambhampati, U.S., 2010. Formal and Informal Institutions and Development. World Development, 38(2), pp.137-141.

Chen, H. et al., 2012. Livelihood sustainability and community based co-management of forest resources in China: Changes and improvement. Environmental Management, 49, pp.219-228.

Cope, J., 2003. Researching entrepreneurship through phenomenological inquiry: philosophical and methodological issues., Available at: http:// 
eprints.lancs.ac.uk/30697/.

Cox, M., Arnold, G. \& Tomas, S.V., 2010. A review of design principles for community-based natural resource management. Ecology and Society, 5(4), p.38.

Creswell, J.W., 1998. Qualitative Inquiry and Research Design: Choosing among Five Traditions. Sage Publications, California.

Dietz, T., Ostrom, E. \& Stern, P.C., 2003. The struggle to govern the commons. Science, 302(2003), pp.1907-1912.

Dixon, A. \& Wood, A., 2007. Local institutions for wetland management in Ethiopia: Sustainability and state intervention. In B. van Koppen, M. Giordano, \& J. Butterworth, eds. Communitybased water law and water resources management reform in developing countries. Wallingford: CABI International, pp. 130-145.

Finlay, L., 2009. Debating Phenomenological Research Methods. Phenomenology \& Practice, 3(1), pp.6-25.

Flood, A., 2010. Understanding phenomenology. Nurse researcher, 17, pp.7-15.

Gatto, P. \& Bogataj, N., 2015. Disturbances, robustness and adaptation in forest commons: Comparative insights from two cases in the Southeastern Alps. Forest Policy and Economics, 58, pp.56-64.

Gioia, D., Corley, K. \& Hamilton, A., 2012. Seeking qualitative rigor in inductive research: Notes on the Gioia Methodology. Organizational Research Methods, 16(1), pp.15-31.

Giorgi, A., 2006. Difficulties encountered in the application of the phenomenological method in the social sciences. Analise Psicologica, 3(XXIV), pp.353-361.

Giorgi, A., 1997. The theory, practice, and evaluation of the phenomenological method as a qualitative research procedure. Journal of Phenomenological Psychology, 28(2), pp.235-26o.

Hayes, T.M., 2010. A challenge for environmental governance: Institutional change in a traditional common-property forest system. Policy Sciences, 43, pp.27-48.

Helida, A. et al., 2015. The Ethnography of Kerinci. Komunitas International Journal of Indonesian Society and Culture, 7(2), pp.283-296.

Hodgson, G.M., 2006. What are institutions? Journal of Economic Issues, XL(1), pp.1-25.

Indrawardana, I., 2012. Kearifan lokal adat masyarakat Sunda dalam hubungan dengan lingkungan alam. Komunitas, 4(229), pp.1-8.

Kajembe, G.C. et al., 2003. The role of traditional institutions in the conservation of forest resources in East Usambara, Tanzania. International Journal of Sustainable Development E World Ecology, 10(2), pp.101-107.

Kamoto, J. et al., 2013. Doing more harm than good? Community based natural resource management and the neglect of local institutions in policy development. Land Use Policy, 35, pp.293-301.
Kellert, S.R. et al., 200o. Community natural resource management: promise, rhetoric, and reality. Society \& Natural Resources, 13, pp.705-715.

Lasco, R.D. \& Pulhin, J.M., 2006. Environmental impacts of community-based forest management in the Philippines. International Journal of Environment and Sustainable Development, 5(1), pp.46-56.

Li, T.M., 2002. Engaging simplifications: Community based resource management, local processes and state agendas in Upland Southeast Asia. World development, 30(2), pp.265-283.

McCay, B.J. \& Jentoft, S., 1998. Market or community failure? Critical perspectives on common property research. Human Organization, 57(1), pp.21-29.

Mowo, J.G. et al., 2013. The importance of local traditional institutions in the management of natural resources in the highlands of East Africa. Human Organization, 72(2), pp.154-163.

Noble, H. \& Smith, J., 2015. Issues of validity and reliability in qualitative research. Evidence-Based Nursing, 18(2), pp.34-35.

Osei-Tutu, P., Pregernig, M. \& Pokorny, B., 2015. Interactions between formal and informal institutions in community, private and state forest contexts in Ghana. Forest Policy and Economics, 54, pp.26-35.

Pandit, R. \& Bevilacqua, E., 2011. Forest users and environmental impacts of community forestry in the hills of Nepal. Forest Policy and Economics, 13(5), pp.345-352.

Porter-Bolland, L. et al., 2012. Community managed forests and forest protected areas: An assessment of their conservation effectiveness across the tropics. Forest Ecology and Management, 268, pp.6-17.

Rahman, H.M.T. et al., 2014. Informal institutional responses to government interventions: Lessons from Madhupur National Park, Bangladesh. Environmental Management, 54, pp.1175-1189.

Rasolofoson, R.A. et al., 2015. Effectiveness of Community Forest Management at reducing deforestation in Madagascar. Biological Conservation, 184, pp.271-277.

Stevens, C. et al., 2014. Securing Rights, Combating Climate Change. How Strengthening Community Forest Rights Mitigates Climate Change, Washington, DC: WORLD RESOURCES INSTITUTE.

Sumarmi. 2015. Local wisdom of Osing people in conserving water resources. Jurnal Komunitas, 7(1), pp.43-51.

Tang, C.P. \& Tang, S.Y., 2010. Institutional adaptation and community-based conservation of natural resources: The cases of the Tao and Atayal in Taiwan. Human Ecology, 38, pp.101-111.

Tengö, M. et al., 2007. Taboos and forest governance: informal protection of hot spot dry forest in southern Madagascar. Ambio, 36(8), pp.683691.

Uphoff, N.T., 1992. Local Institutions and Participa- 
tion for Sustainable Development Gatekeeper., London, UK: International Institute for Environment and Development (IIED). Available at: http://pubs.iied.org/pubs/pdfs/6045IIED. pdf.

Urech, Z.L., Sorg, J.P. \& Felber, H.R., 2013. Challenges for community-based forest management in the Koloala site Manompana. Environmental Management, 51, pp.602-615.

Wakjira, D.T., Fischer, A. \& Pinard, M.A., 2013. Governance change and institutional adaptation: A case study from Harenna Forest, Ethiopia.
Environmental Management, 51, pp.912-925.

Werthmann, C., 2015. What makes institutional crafting successful? Applying the SES to case studies from India and the greater Mekong Region. Environmental Science E Policy, 53, pp.165-174.

Wimpenny, P. \& Gass, J., 200o. Interviewing in phenomenology and grounded theory: is there a difference? Journal of advanced nursing, 31(6), pp.1485-1492.

Wojnar, D.M. \& Swanson, K.M., 2007. Phenomenology an exploration. Journal of Holistics Nursing, 25(3), pp.172-18o. 